\author{
Textbook: Focus on Students' National Identity
}

\title{
New Chinese Language Tutorial: Development Algorithm
}

\author{
Tatiana L. Guruleva* (a) \\ (a) Moscow City University, 129226, Moscow (Russia), 4-1, $2^{\text {nd }}$ Selskokhoziastvenny Proezd; \\ Far Eastern Studies Institute of Russian Academy of Sciences, 117997, Moscow (Russia), \\ 32 Nakhimovskii prospect \\ gurulevatatiana@mail.ru
}

\begin{abstract}
In conditions that see an increased public interest in the Chinese language study, the Russian education system faces a difficult task of rapidly developing a sufficient number of new effective teaching materials. New educational publications should not only meet the emerging demand for a broad study of the Chinese language, but also fully meet the requirements of modern pedagogical science for textbooks and tutorials. The article features the algorithm for creating a textbook on the Chinese language. In the course of the research, within the framework of the systematic approach, the methods of theoretical and comparative analysis, modeling, longitudinal pedagogical experiment, synthesis and generalization were implemented. As a result of the research, a model of the algorithm for creating a textbook on the Chinese language was proposed. This model includes 11 steps. The analysis of the testing results allowed to conclude about the effectiveness of the developed algorithm. The practical significance of the proposed algorithm for creating a textbook in the Chinese language is that its use will improve quality of the developed textbooks and tutorials in the Chinese language, which, in turn, will contribute to improving quality of Chinese language teaching in schools and universities.

Keywords: Chinese language tutorial, tutorial design algorithm.
\end{abstract}

\section{(C) 2021 Tatiana L. Guruleva}

This is an open access article distributed under the terms of the Creative Commons Attribution License (CC BY 4.0), which permits unrestricted use, distribution, and reproduction in any medium, provided the original author and source are credited.

Published by Moscow City University and peer-reviewed under responsibility of TSNI-2021

(Textbook: Focus on Students' National Identity)

\section{Introduction}

* Corresponding author. E-mail: gurulevatatiana@mail.ru 
Today in Russia Chinese language teaching is carried out in school, university and course profiles. The number of Chinese language learners in Russia constitutes about 56 thousand people, about 19 thousand of which are secondary school students. About 20 thousand students study Chinese at universities. The rest of Chinese language learners number falls on the course profile (Chinese language courses, language schools, Confucius Institutes, etc.). The number of secondary general educational institutions in Russia teaching the Chinese language makes up 168, the number of universities is about 270. In 2015, the Chinese language was included in the subjects list of the All-Russian Olympiad for schoolchildren. In 2019, the Chinese language entered the system of state final certification of Russian schools in the 11th grade.

In Russian school and university profiles, several models of Chinese language teaching have recently emerged. In the school profile, Chinese language study is carried out as a first, as a second and as an optional subject within additional education framework.

The university profile is divided into philological and non-philological, within which the Chinese language is also studied as the first, as the second, in rare cases as the third language. In university profile, it is also possible to study Chinese as an optional subject.

Chinese language teaching in the higher education system is carried out within mastering basic professional educational programs of higher education at Bachelor's and Master's levels such as "Linguistics", "Philology", "International Relations", "Oriental Studies and African Studies", "Foreign Regional Studies", "Pedagogical Education ”, as well as the specialty level "Translation and Translation Studies ”, etc.

An increased demand of society for Chinese language study has set the country's education system a difficult task of developing new teaching materials quickly and efficiently. Such new educational publications are series of textbooks for general educational organizations in Chinese as the second language; new teaching materials for secondary schools in Chinese as the first language; textbooks, tutorials and educational-methodical complexes on the Chinese language for universities. New educational publications should not only meet the emerging demand for a broad study of the Chinese language, but also fully meet the requirements of modern methodological science for textbooks and teaching aids.

\section{Purpose and objectives of the study}

The aim of this study is to develop theoretical and methodological foundations for creating educational resources in the Chinese language, in particular, modeling the algorithm for developing a textbook in the 
Chinese language. I argue that the basis of the textbook development algorithm is creation of a learning technology with all its constituent components.

\section{Literature review}

A review of new educational resources published in Russia (2015-2020) allows us to identify the following trends in the development of educational literature on the Chinese language:

- development of new teaching materials in teaching various aspects of the Chinese language - phonetics (Han, 2016), (Ma \& Voropaev, 2020), grammar (Shchichko, 2016), (Abdrakhimov, Radus \& Tkachuk, 2017), (Belyavskaya, 2016), (Shafir, 2017), etc., stylistics (Kalinin \& Radus, 2018), etc., Chinese language history (Shchichko, Radus \& Abdrakhimov, 2015), (Skvortsov, 2017), etc.

- materials for teaching various types of speech activities in Chinese are intensively developed, in particular: speaking (Zhao, Komendrovskaya \& Borisova, 2016), (Chen, Tsai \& Shevtsova, 2018), etc., reading (Rumyantseva, 2018), listening (Kochergin \& Juan, 2015a), (Kochergin \& Juan, 2015b) and others, writing (Spis, 2015), (Spis, 2016), (Belova, 2017), etc., as well as on interconnected learning of speech activity types (Guruleva \& Qu, 2018), (Kalinin, 2019);

- educational literature in the Chinese language began to cover an increasing number of professional spheres, for example, military sphere, business communication, etc. (Komendrovskaya, 2015);

- teaching materials in teaching translation as a type of professional activity in Chinese and Russian began to be actively developed (Shchichko, 2016), (Skvortsov, 2016), (Popov, 2017), (Kochergin \& Juan, 2017), (Popov, 2020);

- new textbooks began to include not only traditional, but also interactive methods of teaching the Chinese language (round tables, didactic games, design, focus groups, etc.). Their combination with the latest information and communication technologies (social media, Chinese corpora, educational online resources, etc.) helps to increase efficiency of teaching the Chinese language (Guruleva \& Qu, 2018);

- for the first time in Russia electronic textbooks on the Chinese language that do not have a paper version started to appear. In particular, such textbooks are designed at Military University;

- the joint work of Russian and Chinese authors continues to adapt Chinese textbooks to the Russian higher education (Li, Ren, Xu, 2016), (Li, Ren, Xu, 2017); 
- the development of a new textbooks series for secondary school in Chinese as the first language has begun, a complete textbooks series for secondary school in Chinese as a second language from grades 5 to 11 has been designed.

Analysis of the existing educational and methodological literature in Chinese language teaching made it possible to highlight some problems:

- weak linking of some developed educational resources to a specific training profile. Some educational and methodical publications are not focused on a specific profile of education (school, university, course);

- lack of orientation of some educational and methodological tools at a certain stage of training. The authors of teaching materials use different approaches to determining learning stages and levels of language proficiency in Chinese language teaching, they often confuse the concepts of "learning stage" and "language proficiency level";

- absence in some educational publications of accounting for the starting level of Chinese language proficiency, formed among students at the beginning of training in this publication;

- learning goal description in a textbook or study guide without linking it to a specific type / types of competencies being formed and their target levels;

- use of approaches opposite on the basis of classification within the same level of proficiency in the Chinese language. For example, a textbook that mainly relies on a speech approach (dialogues, expressions for memorization, transformation exercises), includes situational lexical and grammatical comments (language approach) that do not provide a full picture of the Chinese language as a system, and unexpectedly end with communicative tasks (communicative approach) and thematic comments of a regional character in Russian (a cultural approach);

- content, methods and technical means selection of teaching in the textbook and teaching aid that do not correspond to profile, stages, goals and target approaches of training, as well as the starting and target levels of proficiency in the Chinese language;

- bulk of textbooks and tutorials do not provide additional books for the teacher and other components of the educational and methodological complex, expanding the possibilities of students in using this publication.

I argue that these problems make it difficult to choose some educational publications as tutorials in each 
individual profile, or, if they are chosen, make training on such educational resources ineffective. At the same time, there are practically no modern works in development of theoretical and methodological foundations of teaching the Chinese language (as a language of a different typological relevance than Russian and European languages) and development of effective tutorials (Guruleva, 2019).

Thus, at present, it is possible to state a contradiction that has arisen between the urgent need to create new educational resources in the Chinese language, on the one hand, and the lack of theoretical and methodological foundations development for creating such resources, on the other.

\section{Methodology}

The research is based on the dialectical method of philosophical methodology, which allows to consider tutorials in the relationship of their types, in interaction with other basic categories of linguodidactics, such as goals, content, methods and teaching technologies. The dialectical method serves as the basis for implementing a general methodological systematic approach to analyzing Chinese language teaching means. From the specific scientific methods of pedagogical science, theoretical methods were applied, such as theoretical and comparative analysis of educational publications in the Chinese language. In order to create an algorithm model for developing a textbook on the Chinese language, a pedagogical modeling method was used. To experimentally test the effectiveness of the algorithm for developing a textbook on the Chinese language, an empirical method was implemented: a longitudinal pedagogical experiment, as well as a method for processing empirical data: a method of qualitative analysis of experimental data. When formulating conclusions, theoretical methods of synthesis and generalization were used.

The experimental base of the study was made up of textbooks and tutorials in Chinese language teaching to domestic scientists, teachers and methodologists. A total of 47 educational publications were analyzed.

The study was conducted in 2015-2020. At the initial stage (2015-2016), an algorithm model for developing a textbook on the Chinese language was drawn up, presented in the textbook "Practical course of verbal communication in Chinese" (Guruleva T.L., Qu, 2018). At the second stage of the study (20172018), this algorithm was expanded through a theoretical study of the Framework for Chinese as a foreign language, the results of which were published in the monograph "A Common Framework for Chinese. Results of a comparative linguodidactic study". At the third stage of the study (2018-2019), the theoretical provisions of theoretical and methodological foundations of teaching were clarified, and were published in the monograph "Theory of teaching the Chinese language and translation in the Chinese-Russian language pair" (Guruleva, 2019). Currently (2020-2021), the development of the "Book for the teacher" is underway, which is part of the educational and methodological complex "Practical course of speech communication in 
Chinese", which is one of the components of the developed algorithm.

\section{Results}

When developing textbooks and tutorials for specific pedagogical problems solution, it is advisable to develop teaching technologies. By a teaching technology, I assume a set of means and methods for reproducing theoretically grounded learning and education processes that allow successfully implementing the set learning goals. The creation of each teaching technology involves selection and combination of teaching methods and means that correspond to the entire set of existing pedagogical conditions at a specific point in the pedagogical process: a specific training profile (school or university), a stage (initial, middle or senior) formed at the beginning of the training period to the starting level possession of students' communicative competence (levels 1 - 6), a given period, duration and volume of training (established by the curriculum), subject teaching goals (what competence or its component and at what level must be formed) and the chosen approach. Based on the listed conditions, training content selection as well as appropriate methods and training means, that consider students' individual educational needs, will take place. When creating a teaching technology, there is no need, for example, when teaching speaking, to use all types of exercises recommended for the formation of this type of speech activity and all possible information educational resources. This approach will be ineffective.

A textbook or study guide, developed on the basis of a specific teaching technology, will solve all the assigned teaching tasks and act as an effective teaching tool in specific pedagogical conditions. Therefore, the basis of the textbook development algorithm is creation of a specific teaching technology with all its constituent components.

I argue that the algorithm for developing textbooks and teaching aids can be as follows:

1. Determination of the training profile of the textbook or teaching aid target audience (school, university or extracurricular courses).

2. Determination of training stage (beginner, intermediate or senior). The learning stage is a time period (interval) of mastering a foreign language. In accordance with this, the classification of training stages implies time frames allocation. Traditionally, in the teaching methodology, the initial, middle and senior stages of training are distinguished. The name of the stages contains a time characteristic reflecting their hierarchy and duration. For the school profile, education stages are primary and partially secondary. For a university profile, training stages can be primary, secondary, and also senior. 
3. Determination of the starting level of intercultural communicative competence formation (1 - 6 levels, correlated with A1 - C2 levels of the common European competences of foreign language proficiency). The framework for Chinese as a foreign language is a specific system with unique level descriptors developed by Chinese experts, which we studied earlier (Guruleva, 2019). The level of Framework for Chinese is defined as zero if the language has not been taught before.

4. Determination of the period (for what classes or courses the textbook is intended), duration (for how long it is intended to use it: academic year, two years, semester, etc.) and training volume (how many training hours it is designed for).

5. Determination of the learning goal (intercultural communicative competence or some of its separate components formation).

6. Determination of the target level a given competence or its component formation (what level of competence or its component should be achieved as a result of training on an educational resource).

7. Determination of the approach to training. The use of one or another approach in teaching the Chinese language or their reasonable combination is determined, first of all, by the specific teaching goal in a certain subject (whether the communicative competence is formed completely, or only its individual components) and the given target level of communicative competence, or its individual components formation ... Teaching the Chinese language at levels 1 and 2 (A1 and A2) must begin with language competence formation, therefore, the language approach will be predominant. Education at levels 3 and 4 (B1 and B2) is characterized by a transition from a predominantly linguistic approach to communicative and intercultural ones. At these levels, other components of communicative competence (speech, discursive, sociocultural) begin to develop to a greater extent. At the 5th and 6th levels of the communicative competence of the Chinese language $(\mathrm{C} 1$ and $\mathrm{C} 2)$, the predominant approach to learning is intercultural, when intercultural, strategic components are formed and the previously named components of intercultural communicative competence continue to form. The use of a speech approach in teaching Chinese is justified only when teaching in a natural language environment - in China takes place.

8. The choice of the theoretical basis of study subject. When developing educational resources, it is necessary to choose the theoretical basis that the author will adhere to in the process of selecting content and choosing methods and teaching aids. For example, teaching the syntactic structure of a Chinese sentence should be carried out based on one of the existing syntactic theories developed by both domestic and Chinese researchers. These theories have certain differences and their chaotic mixing does not lead to a systematic understanding of Chinese syntax. Depending on the chosen theoretical basis, selection of 
training content, methods and appropriate educational information tools is carried out.

9. Selection of training content in accordance with the author's theoretical stand.

10. The choice (or development of own) methods and information tutorials necessary for these methods, corresponding to the profile, training stages, language proficiency level, goals, approaches and training content, taking into account specific training principles. We have previously described modern information technologies for teaching the Chinese language (Guruleva, 2020).

11. After textbook and study guide design, it is necessary to develop additional components of the educational and methodological complex, making the work on the created textbook more convenient for students and teachers.

The proposed algorithm will systematize the development of educational resources on the Chinese language and translation and make them more effective.

This algorithm was tested in the textbook "Practical course of speech communication in Chinese" desing. This textbook was developed for the university philological profile of training, the training stage is intermediate (at the beginning of training), at the end of training - senior, Chinese language proficiency level: starting level - 4 level, target level - 5 level, training period 3 - 4 courses, duration of training 1 or 1 , 5 academic years (depending on the number of hours in the curriculum), the minimum total volume is 200 classroom hours, the goal is intercultural communicative competence formation, the predominant approaches are communicative and intercultural. In the process of testing the textbook in groups of students in 2016-2019. the assessment of knowledge level of the Chinese language was carried out upon completion of subject "Practical course of speech communication" by passing the international exam in Chinese language HSK level 5. In 2016, the number of those who passed the exam was 63\%, in 2017 $57 \%$, in $2018-74 \%$, in $2019-69 \%$ of students in the experimental groups.

\section{Discussions}

In the historical process of developing Chinese language proficiency competencies, there has been a difference in the ratio of Chinese language proficiency levels to the levels of the national Chinese HSK exam. Thus, the first system of competencies for proficiency in Chinese as a foreign language, developed in 2007, included 5 levels, and the HSK exam that existed at that time had 3 parts and included 11 levels, while only levels from 3 to 11 were certified. In 2009, the ratio of Chinese language proficiency levels and HSK exam levels have changed with the introduction of the new HSK exam, and is as follows: 5 levels of Chinese proficiency have become 6 levels of HSK. In 2014, in connection with the development of a new 
Unified Chinese Language Teaching Program for Confucius Institutes, 6 levels of Chinese language proficiency were correlated with 6 levels of the HSK exam and 6 levels of the Common European Framework of Reference for Languages. A new version of the HSK 3.0 exam is currently being introduced, which includes 12 levels, which will set a new correlation between the HSK exam levels with the 6 levels of Chinese proficiency developed in 2014. Obviously, the upper and lower thresholds of the proficiency levels in Chinese as a foreign language and the levels of the HSK exam will coincide, only the internal boundaries of the ratio of these levels will change. This situation, in our opinion, will somewhat complicate the determination of the starting and target levels of Chinese language proficiency in organizing the Chinese language teaching process in general, and in using the proposed textbook development algorithm in particular, since the professional community has a tradition of correlating the Chinese language proficiency levels with levels of the HSK exam, by analogy with what is accepted in the Common European Framework of Reference for Languages. In the new situation, determination of proficiency levels in the Chinese language will take place in two different-level systems, which may complicate the process of organizing Chinese language teaching and teaching materials deelopment.

What is also controversial, in our opinion, is the method of assessing the effectiveness of a textbook or study guide by passing the HSK exam by students. In our opinion, this method can be used to assess the effectiveness of only those textbooks that are focused on intercultural communicative competence formation as a whole, and not its individual components, and only if students agree or even show a desire to participate in the HSK exam. In other cases, the assessment of teaching technologies effectiveness and corresponding textbooks and tutorials should be carried out by other means, for example, by means of current, intermediate and final control in the studied discipline.

\section{Conclusion}

The use of the proposed algorithm enhances the process of textbooks and tutorials design in the Chinese language, making them more effective in the learning process. The developed algorithm will eliminate the shortcomings that exist today in determining the stages, starting and target proficiency levels in the Chinese language, as well as the periods, duration and volume of training hours in the development of textbooks and teaching aids. The developed algorithm will facilitate the level-by-level definition of learning goals in terms of communicative competence constituent components and choice of the corresponding approaches, methods and information tutorials in textbooks and tutorials on the Chinese language.

The developed algorithm will not only allow making a separate textbook or study guide more effective, but will also help to rank them according to training stages, complexity level and components of the formed 
communicative competence to build a trajectory of teaching the Chinese language within mastering a specific basic professional educational program at a university.

The use of the proposed algorithm will facilitate the level prediction of the final results of Chinese language teaching at school and university. In addition, learning from textbooks and tutorials created with the proposed algorithm will facilitate the assessment of students' Chinese language proficiency level at various stages of school and university education.

Thus, improving the quality of the developed textbooks and tutorials will enhance quality of Chinese language teaching at school, university and course profile.

\section{References}

Abdrakhimov LG, Radus LA, Tkachuk V.V. (2017). Topik i kommentariy v kitayskom yazyke. Uchimsya myslit i govorit po-kitayski [Topic and comment in Chinese. Learning to think and speak Chinese]. Moscow: VKN.

Belova N.D. (2017). Vvedenie v ieroglifiku [Introduction to hieroglyphics]. Moscow: Prospect.

Belyavskaya N.A. (2016). Grammatika sovremennogo kitayskogo yazyka dlya nachinayushchih [Grammar of modern Chinese for beginners]. St. Petersburg: Anthology.

Chen Shumei, Tsai Jianping, Shevtsova N.I. (2018). Razgovornyy kitayskiy yazyk dlya starshih kursov [Spoken Chinese for senior year students]. Moscow: Prospekt, FEFU.

Guruleva T.L. (2019). Teorija obuchenija kitajskomu jazyku i perevodu v jazykovoj pare kitajskij - russkij jazyki [Theory of teaching Chinese language and translation in the language pair Chinese - Russian]. Moscow: VKN Publishing house, 444 p.

Guruleva T.L. (2020) Information Technology in Teaching Chinese: Analysis and Classification of Digital Educational Resources. European Proceedings of Social and Behavioural Sciences. Conference proceedings, 95, 208-218. https://doi.org/ 10.15405/epsbs.2020.11.03.23

Guruleva T.L., Qu Kun (2018). Prakticheskiy kurs rechevogo obshcheniya na kitayskom yazyke [Practical course of speech communication in Chinese]. Moscow: VKN.

Han D. (2016) Prakticheskaja fonetika sovremennogo kitajskogo jazyka [Practical phonetics of the modern Chinese language]. St. Petersburg: Karo. 
Kalinin O.I. (2019). Kitajskij jazyk: 4-yj uroven' jazykovoj kompetencii. Razvivaem navyki audirovanija, chtenija, govorenija i pis'ma [Chinese language: 4th level of language competence. We develop listening, reading, speaking and writing skills]. Moscow: VKN Publishing House,.

Kalinin O.I., Radus L.A. (2017). Kurs lekciy po stilistike kitayskogo yazyka [Course of lectures on the stylistics of the Chinese language]. Moscow: VKN.

Kochergin I.V., Juan Lilyan (2015). Kitayskiy yazyk. Audiotrening. Nachalnyy uroven [Chinese. Audiotechnology. Elementary level]. Moscow: VKN.

Kochergin I.V., Juan Lilyan (2015). Kitayskiy yazyk. Audiotrening. Prodvinutyy i zavershayushchiy urovni [Chinese. Audiotechnology. Advanced and final levels]. Moscow: VKN.

Kochergin I.V., Juan Lilyan (2017). Universalnyy multimediynyy prakticheskiy kurs obshchego perevoda kitayskogo yazyka [Universal multimedia practical course of general Chinese translation]. Moscow: VKN.

Komendrovskaya Yu.G. (2015). Delovoy kitayskiy [Business Chinese]. Moscow: Infra-M.

Li Xiaoqi, Ren Xuemei, Xu Jingning. (2016). Kurs kitayskogo yazyka. "Boya Chinese". Nachalnyy uroven. Stupen I [The course of the Chinese language. "Boya Chinese". First level. Stage I]. Beijing: Peking University, St. Petersburg: Karo.

Li Xiaoqi, Ren Xuemei, Xu Jingning. (2017). Kurs kitayskogo yazyka. "Boya Chinese". Nachalnyy uroven. Stupen II [The course of the Chinese language. "Boya Chinese". First level. Stage II]. Beijing: Peking University, St. Petersburg: Karo.

Ma T., Voropaev N.N. (2020). Uchebnik prakticheskoj fonetiki kitajskogo jazyka [A textbook of practical Chinese phonetics]. Moscow: VKN Publishing House.

Popov O.P. (2017). Chastnaya teoriya i praktika perevoda Kitayskiy i russkiy yazyki [Particular theory and practice of translation. Chinese and Russian languages]. Moscow: Flint: Science.

Popov O.P. (2020). Prakticheskij kurs perevoda. Kitajskij jazyk. Uznaj kitaj [Practical translation course. Chinese. Get to know China]. Moscow: R.Valent.

Rumyantseva M.V. (2018). Posobie po chteniju i perevodu sovremennoj hudozhestvennoj literatury Kitaja [A guide to reading and translating contemporary Chinese fiction]. Moscow: Publishing house VKN. 
Shafir M.A. (2017). Grammatika s uprazhneniyami [Chinese. Grammar with exercises]. St. Petersburg: Karo.

Shchichko V.F. (2016). Perevod s russkogo yazyka na kitayskiy. Prakticheskiy kurs [Translation from Russian into Chinese. Practical course]. Moscow: VKN.

Shchichko V.F. (2016). Prakticheskaya grammatika sovremennogo kitayskogo yazyka [Practical grammar of modern Chinese language]. Moscow: VKN.

Shchichko V.F., Radus L.A., Abdrakhimov L.G. (2015). Kurs lekciy po istorii kitayskogo yazyka [The course of lectures on the history of the Chinese language]. Moscow: VKN.

Skvortsov A.V. (2016). Predperevodcheskiy analiz tekstov na kitayskom yazyke [Pretranslation analysis of texts in Chinese]. Moscow: VKN.

Skvortsov A.V. (2017). Kurs drevnekitayskogo yazyka [The course of the ancient Chinese language]. Moscow: VKN.

Spis M.A. (2015). Pishem po-kitayski [We write in Chinese]. St. Petersburg: Anthology.

Spis M.A. (2016). Sbornik uprazhneniy dlya nachalnogo ehtapa obucheniya pismennoy rechi [Collection of exercises for the initial stage of writing instruction]. St. Petersburg: Anthology.

Zhao Tsaihun, Komendrovskaya Yu.G., Borisova E.M. (2016). Razgovornyy kitayskiy. Praktikum po ustnoy rechi [Spoken Chinese. Workshop on oral speech]. Moscow: Infra-M. 